\title{
A Game Theoretic Explanation of Witch Hunting with Special Reference to Assam
}

\author{
Rupamjyoti Nath ${ }^{1 *}$ \\ ${ }^{1}$ Bineswar Brabma Engineering College, INDIA \\ *Corresponding Author: arejayan@gmail.com
}

Citation: Nath, R. (2016) A Game Theoretic Explanation of Witch Hunting with Special Reference to Assam, European Journal of Sociology and Anthropology, 1:2 (2016), 4. doi:10.20897/ ejsa.201604

Received: June 30, 2016; Accepted: December 20, 2016; Published: December 25, 2016

\begin{abstract}
The long-drawn battle between scientific outlook and superstitions has manifested in recent times in India as well as Assam, in particular, in the form of witch hunting. In the background of increasing witch hunting cases surfacing through media reports and number of police cases this paper intends to make an analytical study of the problem with the help of simple game theory techniques considering the different group of individuals involved in such criminal incidents (both victims and culprits) as players and also tries to suggest possible moves to eradicate the problem from a purely technical point of view. Based on secondary data sources, this paper is analytical in nature. Outcomes of Game simulations have depicted the process of victimization as well as the factors responsible for deviations of Nash Equilibrium solutions from socially desirable set of solutions. A careful note on the factors responsible for this deviation can enable the policy makers to formulate effective policies to shift Nash-equilibrium solutions to socially desirable one. It is possible to outline conscious human behaviour that leads to crimes such as witch hunting and identify the parameters controlling which these types of crimes can be controlled.
\end{abstract}

Keywords: game theory, Assam, witches, Nash equilibrium, pay off matrix

\section{INTRODUCTION}

Witch hunting is a social menace which is triggered by lack of information or wrong information and fuelled by superstitions. This is a crime against an individual (usually a woman) or a few persons committed by many, most often incited by another few or another individual with some vested interest against the victim. The triggering information gap may be situational or intentional. This paper attempts to visualize the problem of witch hunting in an objective manner by using the mathematical tool commonly known as Game theory by considering several parameters observed through different literatures and newspaper findings. In order to make the analysis possible different situations of two persons' game have been formulated. The players in the game have been assigned with some payoffs depending on their strategies. These payoffs are subjective in nature.

The broad objectives of every Game in this analysis are two. (a) To find out where the Nash equilibrium ${ }^{1}$ of the game exists, if there is any and also to find out where the socially desirable set of strategies exist. (b) After finding out the variables responsible for this difference we shall try to find out the necessary measures to be taken in order to affect the concerned variables and thus to move the Nash equilibrium to the socially desirable point. Therefore, this analysis is both positive and normative in nature.

\footnotetext{
${ }^{1}$ If there are two players A and B then Nash Equilibrium means that pair of strategies in which A's choice is optimal (yielding maximum profit or minimum loss), given B's choice, and B's choice is optimal given A's choice. As a result, the players stick together at that point without any tendency to move away from it.
} 
In order to make a systematic study this paper has been divided into four broad parts. These are Part A, Part B, Part C and Part D. In Part A, an overview of the problem of witch hunting in Assam has been given. In Part B, the problem of witch hunting has been reproduced in order to enable the analysis as a Game theory problem. In Part C, the game simulations showing equilibrium and decisions of different players have been discussed. It also includes an analysis on the Nash equilibrium and socially desirable set of strategies. Lastly, in Part D, findings from previous analysis and recommendations have been outlined.

For better and comprehensive understanding of conflict problems in social sciences, the use of Game Theory is neither new nor common. For example: Economic sanctions have been an instrument of foreign policy for a very long time. The effectiveness of this instrument was questioned through a Game Theoretic model and it was concluded that under a wide range of specified circumstances, the size of the sanction has no impact upon the behaviour of the target country (Tsebelis, 1990).

In another example, it has also been used to depict the insurgency problem in Nigeria (Ochoche, 2013). Through game simulations, this research has shown that if there is significant incentive to cease fire and the cost of terrorism is significantly increased, then the militants will prefer to cease fire.

The effort of explaining witch hunting problem with the help of Game theory is not known. Game theory is a branch of mathematical analysis that studies interactions between two or more players in conflict situation. The concepts of Game theory provide a language to formulate structure, analyse, and understand strategic scenarios (Turocy and Stengel, 2001). Witch hunting problem appears to be a conflict situation between the probable victim and the culprit who accuses the target with an implicit gain in their mind. Therefore, with some assumptions the situation can be transformed into a strategic conflict scenario in the form of a game/ set of games. In the later part of this study it is also seen that legal intervention is not enough in order to curb this problem. Legal interventions must be supplemented with social actions. A comprehensive Game simulation can adequately identify the parameters which need to be corrected in the course of time.

Game theory undertakes to build mathematical models and draw conclusions from these models in connection with interactive decision-making: situations in which a group of people not necessarily sharing the same interests are required to make a decision (Gura and Maschler, 2008).

The only premise we make in this study is that there is no witch-craft in real world and witch hunting cases are result of superstitious minds which are unable to see the scientific logic due to the fog of ignorance.

\section{PART A: AN OVERVIEW OF THE PROBLEM OF WITCH HUNTING IN ASSAM}

\section{The Indian Milieu}

One major challenge while dealing with the study of witch hunting problem is unavailability of reliable adequate data. National Crime Records Bureau (NCRB) in its annual publication 'Crimes in India 2014' mentions only once about witch hunting while discussing about murders and motives. No comprehensive Indian legal provision is in force to criminalize any act of witch hunting except for some states. Any such occurrences of events are registered in the police stations under different sections of Indian Penal Code (IPC) depending on the details of the crime. Therefore, it is very difficult to say the actual numbers of occurrence of such crime. The national database is totally silent if the victim is less than murdered.

Table 1. Top five states in India on the basis of witch-craft as the motive of murder in the year 2014

\begin{tabular}{clc}
\hline Sl. No & State & Total Number of Cases \\
\hline 1 & Jharkhand & 47 \\
\hline 2 & Odisha & 32 \\
\hline 3 & Madhya Pradesh & 24 \\
\hline 4 & Chattisgarh & 16 \\
\hline 5 & Gujarat & 10 \\
\hline India (Including all states and Union Territories) & $\mathbf{1 5 6}$ \\
\hline Source: National Crime Records Bureau, 2014
\end{tabular}

The states with highest witch hunting murder are the ones with large tribal population and poor socio economic infrastructure with gender disparity. 
European Journal of Sociology and Anthropology, 1:2 (2016), 4

Table 2. Selected socio economic parameters of the five states with highest witch hunting murder

\begin{tabular}{|c|c|c|c|c|c|c|}
\hline \multirow{2}{*}{ S1. No } & \multirow{2}{*}{ State } & \multirow{2}{*}{$\begin{array}{l}\text { Percentage of } \\
\text { Scheduled } \\
\text { Tribes } \\
\text { Population to } \\
\text { total } \\
\text { Population }\end{array}$} & \multicolumn{2}{|c|}{$\begin{array}{l}\text { Poverty Status } \\
\text { (Year 2011-12) }\end{array}$} & \multicolumn{2}{|c|}{ Literacy } \\
\hline & & & $\begin{array}{l}\text { Poverty } \\
\text { Rate }\end{array}$ & $\begin{array}{c}\text { Rural } \\
\text { Poverty }\end{array}$ & $\begin{array}{c}\text { Literacy Rate and } \\
\text { Relative Rank* }\end{array}$ & $\begin{array}{c}\text { Female Literacy } \\
\text { Rate and } \\
\text { Relative Rank* }\end{array}$ \\
\hline 1 & Jharkhand & $26.2 \%$ & $36.96 \%$ & $40.84 \%$ & $\begin{array}{c}67.63 \% \\
(32) \\
\end{array}$ & $\begin{array}{c}56.21 \% \\
(33)\end{array}$ \\
\hline 2 & Odisha & $22.8 \%$ & $32.59 \%$ & $35.69 \%$ & $\begin{array}{c}73.45 \% \\
(25) \\
\end{array}$ & $\begin{array}{c}64.36 \% \\
(26)\end{array}$ \\
\hline 3 & Madhya Pradesh & $21.1 \%$ & $31.65 \%$ & $35.74 \%$ & $\begin{array}{c}70.63 \% \\
(28)\end{array}$ & $\begin{array}{c}60.02 \% \\
(28)\end{array}$ \\
\hline 4 & Chattisgarh & $30.6 \%$ & $39.93 \%$ & $44.61 \%$ & $\begin{array}{c}71.04 \% \\
(27)\end{array}$ & $\begin{array}{c}60.59 \% \\
(27)\end{array}$ \\
\hline 5 & Gujarat & $14.8 \%$ & $16.63 \%$ & $21.54 \%$ & $\begin{array}{c}79.31 \% \\
(18)\end{array}$ & $\begin{array}{c}70.73 \% \\
(20)\end{array}$ \\
\hline & India & $8.6 \%$ & $21.92 \%$ & $25.70 \%$ & $74.04 \%$ & $65.46 \%$ \\
\hline
\end{tabular}

Note: * Relative Rank implies the rank of the state concerned among total 35 (States and Union Territories together) in 2011 census Sources: 1) Population and Literacy: Census of India, 2011

2) Poverty: Planning Commission, 2013

It is an irony that the few states with anti-witch hunting legislation include Jharkhand, Odisha and Chattisgarh also. The law criminalizing witch hunting has failed to deliver the intended result. The Assam assembly in 2015 also passed the Assam Witch Hunting (Prohibition, Prevention and Protection) Bill, 2015 making any offence under the Act as non-bailable, cognizable and non-compoundable to eliminate the superstition from society.

\title{
Witch Hunting in Assam
}

\begin{abstract}
"The State of Assam, occupying a geographical area of 78, 438 square k.ms is a part of the 2, 62,500 square k.ms North-Eastern (NE) region of India. The entire region is not only economically, ecologically, biologically and climatically diverse, but also diverse in terms of demography and culture. The region is the abode of more than 250 tribes, speaking more than 190 languages and dialects. About 84 per cent of the population lives in rural areas, the figure for the state of Assam being about 87 per cent. The region has lagged behind the rest of the country in terms of several parameters and is still economically very backward. More than 130 lakh people live below poverty line, the poor constituting more than one-third of its population (34.4 per cent), against the all India poverty ratio of 26 per cent. In this backdrop, it is quite expectant to encounter rampant ignorance, illiteracy and superstitions among the rural tribal folk. Assam's social landscape constitutes to be locked in an uneasy coexistence between the modern and the barbaric." (Saikia, 2015)
\end{abstract}

Among all the different tribes residing in Assam with their different cultural and linguistic identities, Assamese acts as the lingua franca in their day to day life. The Assamese word for witch is 'Daini'- a gender biased word used specifically for women. This implies, in Assam, the victims targeted are mainly women and their family members with occasional exceptions. 'Daini' in Assam is used to identify a female (or rarely a male) who is supposed to have magical powers that it uses to bring evil to the community. In most cases, witches are woman who are suspected to possess black magic power to harm others or even cause death to the villagers where she lives. In fact, many of those accused of witchcraft are simply helpless women and children, the elderly or the mentally ill, and are sometime the victims of an accuser's personal grudge. In many cases, they are killed mercilessly. Witch hunting is killing of a witch, a superstitious evil practice quite common among Rabha, Hajong, Mising, Bodo and Adivasi communities in Assam. Geographically, the districts in which these communities reside and from where most of the cases appear in the news are Goalpara, Kokrajhar, Chirang, Baska, Sonitpur, Udalguri, Tinsukia, Dhemaji, etc. These are also the districts where the scheduled tribe population is high compared to the state average and level of literacy and healthcare is low. 
Table 3. Some socio-economic parameters of eight districts in Assam with frequent witch hunting cases

\begin{tabular}{cllccc}
\hline $\begin{array}{c}\text { S1. } \\
\text { No }\end{array}$ & Districts & $\begin{array}{l}\text { Main Communities } \\
\text { involved in witch hunting }\end{array}$ & $\begin{array}{c}\text { Percentage of } \\
\text { Scheduled Tribes to } \\
\text { Total Population }\end{array}$ & Literacy Rate & $\begin{array}{c}\text { Female Literacy } \\
\text { Rate }\end{array}$ \\
\hline 1 & Goalpara & Rabha, Hajong & $22.97 \%$ & $67.37 \%$ & $63.13 \%$ \\
\hline 2 & Kokrajhar & Adivasi, Bodo, Rajbongshi & $31.41 \%$ & $65.22 \%$ & $58.27 \%$ \\
\hline 3 & Chirang & Bodo, Rajbongshi & $37.06 \%$ & $63.55 \%$ & $56.65 \%$ \\
\hline 4 & Baksa & Bodo & $34.84 \%$ & $69.25 \%$ & $61.27 \%$ \\
\hline 5 & Sonitpur & Adivasi, Bodo & $12.07 \%$ & $67.34 \%$ & $60.73 \%$ \\
\hline 6 & Udalguri & Adivasi, Bodo & $32.15 \%$ & $65.41 \%$ & $58.05 \%$ \\
\hline 7 & Tinsukia & Adivasi & $6.18 \%$ & $69.66 \%$ & $61.73 \%$ \\
\hline 8 & Dhemaji & Mising & $47.45 \%$ & $72.70 \%$ & $65.21 \%$ \\
\hline & & Assam & $\mathbf{1 2 . 4 5 \%}$ & $\mathbf{7 2 . 1 9 \%}$ & $\mathbf{6 6 . 2 7 \%}$ \\
\hline
\end{tabular}

Source: Statistical Handbook. Assam 2014 (Government of Assam)

There are several distinct steps in the whole process of witch hunting that came up in the primary survey. Chronologically, they are mainly:

(i) Encountering a problem by one or many in the community which appears inexplicable for them with their knowledge,

(ii) Search for the person responsible (i.e. the witch): Generally, in a village or within the locality there is a traditional sorcerer, locally called Ojha, who looks into the matter and reveals the name of a particular woman (or rarely a man) who is held responsible for the problem concerned. She/he is then considered as a "daini" harming the village.

If the problem faced at the first step is outbreak of some disease then sometime, the ill person is also tortured forcing to spell out the name of witch. Usually a sick person in his or her state of illness spells out the name of the person against whom they have a personal grudge.

(iii) Once the name is known, the people who are already superstitious starts to corroborate the story with their past misfortunes relating them to the probable witch. These people are further incited by some other people with vested interests.

(iv) The next crucial step is to confront the witch and asking her/him to confess about the crimes and misfortunes they are responsible for. The clueless and helpless victim facing a situation of 'one against all', at first, denies all allegations. But eventually after tortured brutally by the mob incited by some other with vested interest the victim woman usually breaks down and reluctantly confesses herself as witch to get rid of the torture. The method of torture varies from community to community.

(v) Finally, it is the time to decide the fate of the witch. Once confirmed the victim is either killed or chased away from the village. In case of women they are sometimes raped before killing 'in order to free her from the power of witchcraft'. All the belongings and the properties of the woman is taken away by the people. At this moment, the members of the family could hardly interfere as if they interfere there is a possibility for them to meet the same fate.

A senior police officer from his direct experience in Kokrajhar district said that if the woman alleged to be a witch is killed, her body is cut into pieces and buried separately as it is believed that putting together all the parts of the body of the 'witch' may result into rebirth of witch. Although in most of the cases women are branded as witches, husbands are also not spared. Sometime, the whole family is wiped out. The pieces of the dead bodies of the witches are buried separately in different places as it is also believed that if they are buried together the witch will take rebirth and harm people.

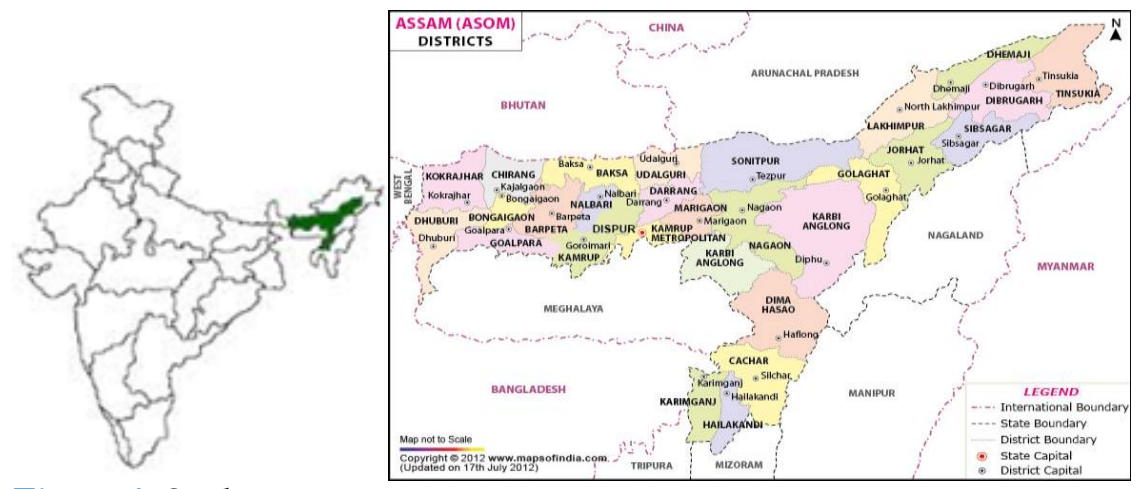

Figure 1. Study area map 
According to available statistics, 81 cases of witch-hunting were reported in the state between 2006 and 2010 . While 57 of these victims were physically tortured, the rest were brutally murdered. Since 2001, 38 cases of witchhunting have been reported in Goalpara district alone (Handique, 2010). As per latest report, 132 people have been killed in the last ten years in the name of witch hunting, a majority of the victims being women (Editorial, The Assam Tribune, $10^{\text {th }}$ Dec, 2013).

Criminal Investigation Department (CID) of Assam data reveals that there is an increase in both number of cases registered and number of persons arrested in witch hunting cases as seen in Table 1 and Figure 2 over time. The increasing gap between the trend lines shows plurality of culprits involved in single cases.

Table 4. Witch hunting cases in Assam

\begin{tabular}{cccccc}
\hline Year & $\begin{array}{c}\text { No. of Cases } \\
\text { Registered }\end{array}$ & $\begin{array}{c}\text { Charge } \\
\text { Sheeted }\end{array}$ & $\begin{array}{c}\text { Final } \\
\text { Report }\end{array}$ & $\begin{array}{c}\text { Pending } \\
\text { Investigation }\end{array}$ & $\begin{array}{c}\text { Person } \\
\text { Arrested }\end{array}$ \\
\hline 2008 & 10 & 7 & 3 & 0 & 20 \\
\hline 2009 & 4 & 3 & 1 & 0 & 64 \\
\hline 2010 & 11 & 9 & 2 & 0 & 52 \\
\hline 2011 & 29 & 21 & 4 & 4 & 149 \\
\hline 2012 & 14 & 8 & 1 & 5 & 113 \\
\hline 2013 & 16 & 5 & 0 & 11 & 97 \\
\hline 2014 (up to March) & 1 & - & - & 1 & 1 \\
\hline Total & $\mathbf{8 5}$ & $\mathbf{5 3}$ & $\mathbf{1 1}$ & $\mathbf{2 1}$ & $\mathbf{4 9 6}$ \\
\hline
\end{tabular}

Source: CID, Assam (2015)

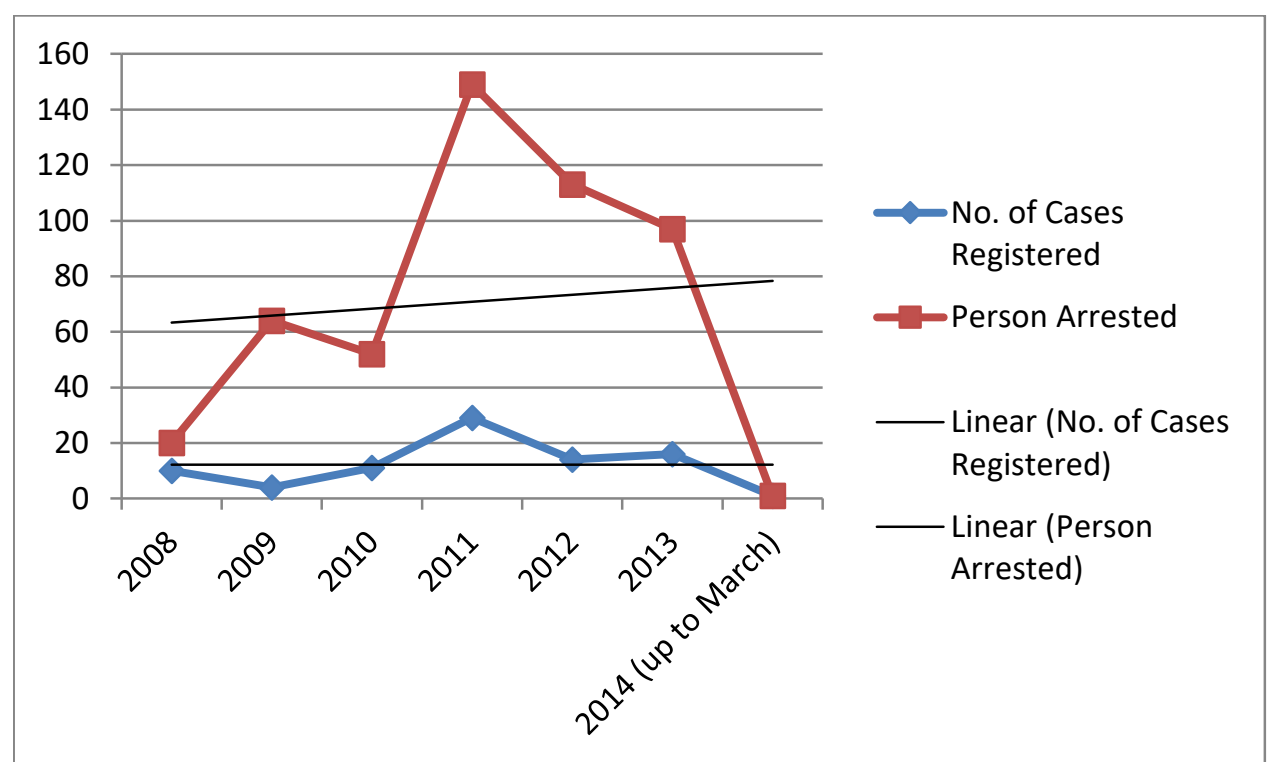

Figure 2. Graphical representation of number of cases registered and persons arrested

The main causes of witch hunting cases in Assam are: Economic and other social factors. The prime Economic causes are: Land Holding and other property related issues, poverty, poor transportation or remote areas, lack of health facilities and health awareness, lack of sanitation facilities, lack of pure drinking water etc. Social factors can be broadly outlined in illiteracy and ignorance, superstition, personal enmity rural power dynamics etc.

The result of witch hunting cases has far reaching effects on the victims. These are: isolation of accused victim and her family, forced migration, mental disturbance leading to psychological imbalance and becoming mad, attempt to suicide, loss of property, loss of livelihood and difficulty to get absorbed in the job market, compromised children's education leading to forced drop out, susceptible to human traffickers, loss of life $(15 \%$ have lost their lives) etc.

It is rightly observed "Witch-hunting is like an infectious disease and is slowly spreading to newer areas and solutions will have to be found to eradicate this evil practice." 2

Senior Indian Police Service (IPS) officer Kula Saikia who worked extensively on the issue of witch hunting, is considered as the brain behind Project Prahari (means 'the sentinel'), an active campaign against this social prejudice. Project Prabari was launched in the year 2001 during his service in Kokrajhar district and the crusade

2 Zee News. National Commission for Women asks police to find solutions to witch-hunting in Assam (Nov 18, 2008), available at http://www.zeenews.com/states/2008-11-18/484620news.html 
under the patronage of police department included community policing measures, promotion of health camps and health awareness besides regular awareness campaigns among tribal chiefs and village elders.

Another forerunner in the crusade against witch hunting in Assam is Birubala Rabha of Goalpara district who was also branded as witch at one point of time in her past. She is responsible for saving many innocent women and families from being witch hunted under 'Mission Birubala'. She has been conferred with many awards including honorary doctorate degree by Gauhati University in 2015 in honour of her relentless service for decades since 1980s. It is also noteworthy that she was one of the nominees for the Nobel Peace Prize awards from India by Northeast Network- an NGO in the year 2005.

\section{PART B: INTRODUCING THE GAME IN WITCH-HUNTING}

"In the normal-form representation of a game, each player simultaneously chooses a strategy, and the combination of strategies chosen by the players determines a payoff for each player" (Gibbons, 1992: 2). The process of formally modelling a situation as a game requires the decision-maker to enumerate explicitly the players and their strategic options, and to consider their preferences and reactions (Turocy and Stengel, 2001). Therefore, it becomes mandatory to identify the players, strategy and payoffs to understand the game of witch-hunting too.

In this connection three points need to be explained first.

First : The outline of the Game.

Second : The concept of the strategies.

Third : The value of the payoffs determined by the combination of strategies of both players.

\section{Outline of The Game}

- Each one is two-person non-zero sum game 3 .

- General assumptions on which any game is formed are:

(a) The players involved are rational trying to maximize their utility.

(b) Players have complete knowledge of the game: (i) regarding the rules of the game which remains constant throughout the game; (ii) regarding the payoffs of their own as well as of the opponents.

- In order to represent the menace of witch hunting in a game theoretic way, different entities have been considered as a player in the discussion. Players are the parties or individuals involved in a game. Each of them are mentioned below:

1. Nature or natural factors.

2. Community concerned where the crime of witch hunting is likely to occur or have occurred.

3. The victim/victims are the aggrieved persons from any occurrence of witch hunting incident targeted by the culprit or the community.

4. The culprit/culprits are those specific member/members of the community who intends to gain in the course of time by acting on his own or inciting the other members of the community against the victim/victims. "It is young men, often unemployed, who provide the manpower for the witch-bunts, although often executing plans hatched by other actors who remain in the shadow" (Federici, 2008: 7). We call these shadows as culprits.

5. State and non-state civil society body represents the Government Officials, NGOs, Press, and Women's Organization etc.

6. Police is distinct from society. It is the law enforcing unit different from society as a whole whose aim includes collecting evidence once any crime happens and ensure justice.

7. Media represents both print and electronic media.

The ultimate goal of game theory is to find the optimum strategy in which all players involved maximizes their utility. This strategy though, might not be the preferred strategy for an individual player who is assumed to be rational. Game theory seeks to predict the strategy and hence give advice on how to play the game against rational opponents (Ochoche, 2013).

\footnotetext{
${ }^{3}$ In a 'two-person zero-sum' game there are two players (or more generally two parties with conflicting interests) and 'zero sum' means the loss of one player implies the gain of the other resulting the total sum of their payoffs to zero for each pair of strategies. Likewise, in a 'non-zero sum game' one player's payoff does not depend on the payoff of the other player resulting total sum of the payoffs are not necessarily zero.
} 


\section{Concept of Strategy}

Strategy means the course of action that the player chooses. A strategy can be pure or mixed. It is pure when the player chooses a strategy once and for all. But in a mixed strategy one element of probability is assigned to each strategy. Both types of these will be dealt with in different games.

\section{Payoff Matrices}

Payoffs are gain or losses incurred to the players in a game as a result of choosing a particular strategy among all the strategies available to him given the other player's strategy. A payoff matrix is the systematic arrangement of strategies and payoffs of two players in a game. While discussing this model, we have assigned some payoffs to each of the players in discussion depending on the available strategies of each player. Payoffs in this model deserve three points to be explained:

(a) Witch hunting being a social problem, these payoffs can not be expressed in numbers (i.e. cardinal manner). Therefore, we have resorted to ordinal way meaning the payoffs are not expressed in numbers but when we compare we can arrange the payoffs of one particular player in ascending or descending manner. This also implies that the player can prefer one strategy to another depending on the gain or loss by doing so but can not exactly express the difference in his gain or loss in terms of quantitative value. Moreover, we have expressed some subjective parameters such as honour, disgrace and emotions etc. in the form of payoff.

(b) These payoffs are alphanumeric in limited sense. Zero is the only number and other payoff values are represented by alphabets. Moreover, it is further assumed that every successive alphabet represents higher value than the previous one. In other words, symbolically, $\mathrm{A}<\mathrm{B}<\mathrm{C}<\mathrm{D}<\mathrm{E}<\ldots<\mathrm{Y}<\mathrm{Z}$.

(c) In some cases, payoffs are depicted with a negative sign. It simply represents the negative utility derived from choosing a particular strategy. Moreover, the payoffs denoted with asterisk $(*)$ sign signifies that there is a possibility as well as social need for the value of a particular payoff to increase over time.

\section{PART C: DECISIONS AND EQUILIBRIUMS}

Witch hunting incidents are mostly seen in the societies which are closely related to the nature and ignorant of logical rules and modern advancements in science. Their inability to judge logically the natural phenomena gives rise to some quasi-mystical characters in the society. Witch hunting cases being prevalent mostly is remote areas of society can be attributed mainly to the absence of health professionals and consequent existence of local defacto doctors commonly known as Ojhas in the eastern part of India. These Ojhas are powerful local figures within a cluster of villages whose activities range from treatment of diseases even of cancer to fortune-telling and to 'identifying' the evil spirits. They are the businessmen capitalizing on the superstitions and ignorance of common villagers. So long as natural phenomena are inexplicable to common people these Ojhas enjoy prime importance in the society.

Occasional adversities of the nature and society's course of action in response to these decide witch-hunting incidents. Natural factors can affect the villagers in two mutually exclusive ways. Affects all or affects some. The community in response reacts to it depending on their ability of rational thinking and their access to scientific mode for correcting their woes. These can be medical facilities in case of diseases, irrigation facilities in case of draught or easily accessible expert help (such as helpline facilities) in case of any 'inexplicable' phenomenon occurred to them.

In some areas, it is seen that the Natural factors whenever affect the whole community (including the potential victims of witch-hunting), they resort to some traditional rituals such as observing frog marriage in case of no rainfall or worshipping river in case of flood for example. Although these rituals are not harmful directly they keep the community in superstitious environment in case of any coincidental amelioration of their woes. Moreover, instances are not rare when someone from the community is blamed for the agony and is humiliated as a witch resulting in heavy monetary fine (Pradhan and Guzman, 2013). But situation becomes more aggravated when the victim is blamed for 'inexplicable' specific problem such as death of children or persons within the community. Chaudhuri (2014) in the working paper on witch hunting cases among tea plantation workers in Jalpaiguri makes details analysis on how the absence of adequate health-care facilities and health awareness paves the way for superstitions making a vulnerable weak member of the society a scapegoat for witch hunting (Dulari's Story in p.5). The victim is subjected to humiliation, torture or even killing.

Most importantly humiliation and torture hardly come to light as most of these cases go unreported. Only after the murder of the victim, sometimes, it comes to news as 'witch-hunting'. Ironically the victim was neither 'witch' nor an animal to be 'hunted'. These types of news derogate the basic human existence of the victim subjecting the survivors of their family members to further humiliation. 
Table 5. Decision and outcome matrix between the players Nature and the Remote Social Community

\begin{tabular}{ccccc}
\hline $\begin{array}{c}\text { Players } \\
\downarrow\end{array}$ & \multicolumn{4}{c}{ Remote Social Community } \\
\hline & $\begin{array}{c}\text { Strategies } \\
\downarrow\end{array}$ & $\rightarrow$ & Scientific Resort & Superstitious Resort \\
\cline { 2 - 4 } & $\begin{array}{c}\text { Causing Common } \\
\text { Problem }\end{array}$ & A & $\begin{array}{c}\text { Unite and apply } \\
\text { correcting measures }\end{array}$ & $\begin{array}{c}\text { Traditional Rituals follow } \\
\text { (Usually not Harmful) }\end{array}$ \\
\cline { 2 - 5 } & $\begin{array}{c}\text { Inexplicable' } \\
\text { Specific Problem }\end{array}$ & B & $\begin{array}{c}\text { Corrective and } \\
\text { Preventive Measures }\end{array}$ & $\begin{array}{c}\text { Less productive and weak } \\
\text { members are likely to be targeted }\end{array}$ \\
\hline
\end{tabular}

\title{
Summary
}

1. Strategy $(\mathrm{B}, 2)$ triggers witch hunting.

2. 'Inexplicable' depends on the exogenous variables like Health awareness and medical facilities, exposure to the outer world, education, connectivity etc.

3. Shifting people's choice from strategy 2 to strategy 1 i.e. from superstitious resort to scientific resort is a social need and a long-term outcome of social change.

4. In the description of Table 5, it is assumed that "causing common problems" cannot lead to harmful targeting of weak members because in the mind set of people it appears unlikely that a 'witch' will harm itself in order to harm other people of the society.

The main point of importance of the whole discussion is strategy (B, 2) of Table 5. It has been tried to explain how the process of accusing a soft target in the society eventually lead to a front cover news on witch-hunting. In doing so different games have been depicted between different players with their respective payoffs in the following.

\section{GAME SIMULATION: 1}

\section{The game between culprit and victim}

\begin{abstract}
"Various studies undertaken to understand the practice of witch hunting worldwide attribute it to different reasons beyond mere superstition. The vulnerable sections of the society are usually identified as witches with an aim to denounce them from the community and take control over their land, property etc. This is the reason why mostly single women and widows become 'easy scapegoats' and are branded as witches to divest them of their land and property, or punished for transgressing social norms or refusing sexual advances" (Chaudhuri, 2012 as cited in Chakraborty and Borah, 2013).
\end{abstract}

A careful note across different works confirms that vested interest from the part of the culprit plays an important role in witch-hunting cases. This 'vested interest' may be of different types ranging from sexual favours to land possession. We term this as 'apple of discord' (denoted by $R$ ) in the following discussions. With a prime aim of grabbing $R$, the culprit may have different options and the victim also selects one strategy from all the available.
"Most of the time, the cases occur due to personal feud, jealousy, property dispute and of course, superstition. Branding someone a witch is often an excuse to settle scores, or gain at another's expense. Some alleged witch killings are nothing but the handiwork of the land mafia. In such cases, some miscreants use social superstitions to destroy and uproot families completely from the land they have their eye on, so that this piece of property can later be acquired at dirt cheap prices. In some cases, women are branded witches and punished along with their family members after they resist sexual exploitation attempts by some miscreants within the community. Sexual assault appears to be a new phenomenon." (Saikia, 2015)

In Table 6, the payoff matrix between the players: culprit and victim has been depicted. In order to represent their payoffs some parameters have been considered. These parameters are in some cases subjective also. All of these are shown below the table. 
European Journal of Sociology and Anthropology, 1:2 (2016), 4

Table 6. Pay-off matrix between the players Culprit and Victim

\begin{tabular}{|c|c|c|c|c|c|}
\hline Players $\rightarrow$ & \multicolumn{5}{|c|}{ Victim/Victims } \\
\hline \multirow{5}{*}{ 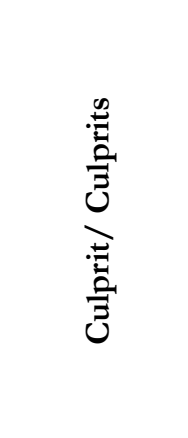 } & \multirow{2}{*}{\multicolumn{2}{|c|}{$\begin{array}{c}\text { Strategies } \\
\downarrow\end{array}$}} & Cooperate & Protest & $\begin{array}{l}\text { Community Help } \\
\text { (Only Case Specific) }\end{array}$ \\
\hline & & & 1 & 2 & 3 \\
\hline & $\begin{array}{c}\text { Leave the } \\
\text { victim Alone }\end{array}$ & A & $(0, R+P)$ & $(0, R+P)$ & Does not Arise \\
\hline & $\begin{array}{l}\text { Pressurize } \\
\text { the Victim } \\
\text { Individually }\end{array}$ & B & $(R,-R)$ & $(0,-P)$ & $\begin{array}{c}-p X \\
-(1-p) Q \\
\end{array}$ \\
\hline & $\begin{array}{l}\text { Involve } \\
\text { Community }\end{array}$ & $\mathrm{C}$ & $\begin{array}{c}R+H, \\
-(R+b) \\
\text { (Nash Equilibrium) }\end{array}$ & $\begin{array}{c}R+H \\
-(R+b+c)\end{array}$ & Does not Arise* \\
\hline
\end{tabular}

$R=$ the 'apple of discord' between the culprit and the victim;

$P=$ The dignity and mental peace of the victim;

$Q=$ The social honour that the victim enjoys. $(Q>P$ as it is the social image that largely decides the self respect of a person);

$p=$ The probability that the community will be convinced against the culprit and are willing to help the victim;

$(1-p)=$ The probability that the community will not be convinced and are not willing to help the victim;

$X=$ The punishment that the culprit will get if convicted;

$H=$ The 'honour' that the culprit will get from the community when he successfully convinces them and prove the victim as

a 'witch';

$b=$ The humiliation faced by the victim when accused as a 'witch';

$c=$ The torture and inhuman 'test' the victim has to go through when she denies to be a witch.

\section{Findings}

1. The Strategy $(C, 1)$ is Nash Equilibrium. It is because when the culprit's strategy is fixed at strategy $C$, the victim has no incentive to move away from Strategy 1 as choosing this Strategy 1 minimizes the loss. And at the same time when the strategy of the victim is fixed at Strategy 1 , the payoff to the culprit is maximum at Strategy $\mathrm{C}$ making him stick to it. Strategy $(\mathrm{C}, 1)$ being the Nash equilibrium, the culprits are more likely to involve community to satisfy his own interest.

2. The Strategy $(\mathrm{C}, 3)$ can be developed over time if the community or a section of the community is exposed to new scientific developments and if the different civil society organs can make others feel their existence.

3. The Strategy $(B, 3)$ is not a Nash equilibrium as when the victim chooses strategy 3 , the culprit/ culprits depending on the probability of getting punished $(p)$ may choose to shift his strategy to A or C.

\section{Illustrations}

In absence of Strategy 3 (Community Help) in the victim's hand, strategy C of culprit (involve community) strongly dominates other two. Therefore, in order to restrict the culprit in the socially desirable strategy i.e. A ('Leave the victim alone') it is necessary to develop an atmosphere in the society where victim does not feel reluctance to ask for community help and there is high chance of culprit to be punished if guilty. (i.e. increased ' $p$ '). Such an atmosphere will also ensure that even if some part of the community is involved in the incident then also there is a possibility that some 'rational thinker' within the community will come forward for the help of the victim.

\section{GAME SIMULATION: 2}

\section{The game between culprit and community}

The culprit's decision of whether the community is to be involved or not in order to satisfy his objective is a crucial one as it is the community or the society who can come in the path of his wicked plan. Successfully convincing the society ensures his success. While discussing about the mobilizing support in the process of witchhunting, Chaudhuri (2014) said

\footnotetext{
"... gathering support against the witch was often both planned and sometimes voluntary. While some of the villagers were persuaded to participate in the witch hunt through alcohol, and sometimes through small amounts of money (as little as fifty rupees), the bulk of the villagers joined without persuasion, and almost no transaction. In all cases gossip played a crucial role. Stories of the 'dain' in the community exist through gossip that forms
} 
networks through which the fears and challenges are transmitted. This mobilization of public support is an important step during witch bunts (p.16)."

Although this observation by the writer was made in the witch hunting cases among the tea plantation workers in Jalpaiguri, the words are equally true in all the cases in Assam too.

In Table 7, the payoff matrix between the players- Culprit and the Community has been depicted with the parameters representing their payoffs as shown below it.

Table 7. Pay-off matrix between the players Culprit and Community

\begin{tabular}{|c|c|c|c|c|c|c|}
\hline Players & $\rightarrow$ & \multicolumn{5}{|c|}{ Community } \\
\hline \multirow{5}{*}{ 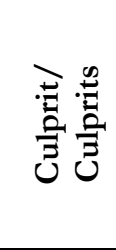 } & & \multicolumn{2}{|l|}{ Strategies $\rightarrow$} & Participate & No Participation & Other Options* \\
\hline & & \multicolumn{2}{|l|}{$\downarrow$} & 1 & 2 & 3 \\
\hline & & Remain Neutral & $\mathbf{A}$ & 0 , Does not arise & 0 , Does not arise & Nil \\
\hline & & Act Alone & $\mathbf{B}$ & $R, f$ & $-p X, f$ & Nil \\
\hline & & Involve Community & $\mathbf{C}$ & $\begin{array}{c}\boldsymbol{R}+\boldsymbol{H}, \boldsymbol{g} \\
\text { (Nash Equilibrium) }\end{array}$ & $\begin{array}{c}-(m X+H) \\
f\end{array}$ & Nil \\
\hline
\end{tabular}

$R=$ the 'apple of discord' between the culprit and the victim;

$f=$ The mental satisfaction that the community enjoys by 'saving' the society from a bad element. The value of $f$ in strategy $(B, 1)$ and $(B, 2)$ are same as it does not matter for the community whether they act against a bad element in the society in the form of 'culprit' or 'someone else' whom the culprit has alleged with some charge (not necessarily as witch);

$p=$ The probability that the culprit is punished;

$X=$ The punishment that the culprit will get if convicted;

$H=$ The 'honour' that the culprit will get from the community when he successfully convinces them and prove the victim as a 'witch';

$g=$ The mental satisfaction that the community enjoys by 'saving' the society from a 'witch' $(\mathrm{g}>\mathrm{f}$, because punishing a witch saves them from future dangers also);

$m=$ The probability that the culprit is punished in spite of the community involvement in the incident ( $\mathrm{m}<\mathrm{p}$ as the more persons are involved the less chance of getting witness by the police).

It should be mentioned that if socially recognized institutions such as religious set up are involved by the culprit in the process then this probability becomes negligible.

\section{"At present, the witch bunting cases are registered as normal murder cases and it is difficult to go for proper documentation of such cases. Moreover, when a whole village is involved in a case, it is difficult to pinpoint the main culprit and it is almost impossible to collect evidence as no one comes forward to testify against anyone" (Superintendent of Police, Kokrajhar District, 2015).}

Same thing happened in the Debjani Bora case in the Karbi Anglong district of Assam in which a national athlete highly decorated with many gold medals was dragged to a community prayer hall to face public trial on charges of being a witch was tied up and severely beaten after being branded as one in her village (BBC, 2014).

\section{Findings}

1. Strategy $(C, 1)$ is the Nash Equilibrium.

2. 'Others options' (i.e. the Strategy 3 of community) may include any other positive role of the members of the society apart from not participate in such happenings (Strategy 2) or participate with the culprit (Strategy 1) such as alerting police and NGOs, handling such situations with a rational way by developing a scientific mind, alert press etc. These options can be developed with vibrant NGOs, Judicial activism, active media and people friendly police setup.

3. The socially desirable strategies are A (of culprit) and 3 (of community)

\section{Illustrations}

Developing options in case of any happenings of such type for the community can put the authority on alert and thus can prevent them to happen. 


\section{GAME SIMULATION: 3}

The game between culprit and community when the third option is developed in the hand of community

In the following table the payoff matrix between the players Culprit and the Community has been depicted with the parameters representing their payoffs as shown below it. There are two differences between Table 7 and Table 8.

(i) In Table 8, the Strategy 3 of the community has been developed and mentioned as 'whistle blow' meaning resorting to informing administration and different concerned social groups.

(ii) A new element of probability in choosing different strategies has been introduced. The community chooses strategy 1, 2 or 3 with respective probabilities $p_{1}, p_{2}$ and $p_{3}$.

Table 8. Pay-off matrix between the players Culprit and Community (with the third option at the Community's disposal)

\begin{tabular}{|c|c|c|c|c|c|c|}
\hline $\begin{array}{c}\text { Players } \\
\downarrow\end{array}$ & $\rightarrow$ & \multicolumn{5}{|c|}{ Community } \\
\hline \multirow{4}{*}{ 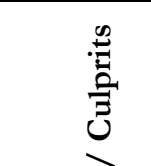 } & & \multirow{4}{*}{$\underset{\downarrow}{\text { Strategies }} \rightarrow$} & & 1 & 2 & 3 \\
\hline & & & & Participate & No Participation & Whistle Blow \\
\hline & & & & \multicolumn{3}{|c|}{ Strategies used with respective Probabilities } \\
\hline & & & & $p_{1}$ & $p_{2}$ & $p_{3}$ \\
\hline \multirow{3}{*}{$\begin{array}{l}\hat{\vec{b}} \\
\frac{\hat{a}}{\vec{b}}\end{array}$} & & Remain Neutral & $\mathbf{A}$ & 0,0 & 0,0 & 0,0 \\
\hline & & Act Alone & B & $R, f$ & $-p X, f$ & $-q X, g$ \\
\hline & & Involve Community & $\mathbf{C}$ & $R+H, g$ & $-(m X+H), f$ & $-(n X+H), f$ \\
\hline
\end{tabular}

$R, f, X, p, g, H, m$ are same as Table 7 .

$n=$ the probability that the culprit is punished when someone in the community alerts other organs of the society.

\section{Findings}

1. From the culprit's point of view his expected payoff from choosing different strategies are:

(a) When Strategy A is chosen

(b) When Strategy B is chosen

$$
E(A)=0
$$

$$
\begin{aligned}
E(B) & =p_{1} R+p_{2}[-(p) X]+p_{3}[-(q) X] \\
& \left.=p_{1} R-\left[p_{2}(p) X\right]+p_{3}(q) X\right]
\end{aligned}
$$

(c) When Strategy $\mathrm{C}$ is chosen

$$
\begin{aligned}
E(C) & =p_{1}(R+H)+p_{2}[-(m X+H)]+p_{3}[-(n X+H)] \\
& \left.=p_{1}(R+H)-\left[p_{2}(m X+H)\right]+p_{3}(n X+H)\right]
\end{aligned}
$$

2. The socially desirable strategy is the culprit should be confined in the Strategy A. it will only be possible if his payoff in Strategy A is higher than the payoffs from rest two strategies available to him. As we have seen his expected payoff in Strategy A is 0 (zero), we must try to make $E(B)$ and $E(C)$ negative. It is possible if $\left.\left[p_{2}(p) X\right]+p_{3}(q) X\right]>p_{1} R$ in case of Strategy $\mathrm{B}$ and $\left.\left[p_{2}(m X+H)\right]+p_{3}(n X+H)\right]>$ $p_{1}(R+H)$ in case of strategy C. In other words, significant increase in probabilities to choose Strategy 2 and $3\left(p_{2}\right.$ and $\left.p_{3}\right)$ and also the probability to get the culprit punished $(m, n, p$ and $q)$ along with the increase in punishment (i.e. $X$ ) can reduce witch hunting.

\section{Illustrations}

Increase in probabilities to choose Strategies 2 and $3\left(p_{2}\right.$ and $\left.p_{3}\right)$ depends on how educated the people are and also on the factor that how easily accessible the civil society organs are from the village (both physical reach and psychological reach). On the other hand, the probability to get the culprit punished ( $m, n, p$ and $q$ ) along with the increase in punishment (i.e. $X$ ) can be changed by suitable government policies and judicial reforms.

\section{GAME SIMULATION: 4}

\section{Media and Community}

In the social problems like witch hunting media can play a very crucial role. If we observe the role of media in a strategic view from the point of game theory a very interesting outcome follows. It depicts why media 
concentrates on TRP (Television Rating Point). In the following table the strategic interactions between media and community has been shown.

Table 9. Pay-off matrix between the players Media and Community

\begin{tabular}{|c|c|c|c|c|}
\hline $\begin{array}{c}\text { Players } \\
\downarrow\end{array}$ & & & Community & \\
\hline \multirow{4}{*}{ 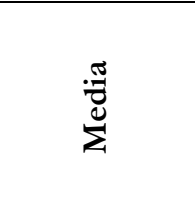 } & \multirow{2}{*}{\multicolumn{2}{|c|}{$\begin{array}{c}\text { Strategies } \\
\downarrow\end{array}$}} & Buy the Information & Remain Indifferent \\
\hline & & & 1 & 2 \\
\hline & TRP Oriented & $\mathbf{A}$ & $\begin{array}{c}K, F \\
\text { (Nash Equilibrium) }\end{array}$ & $J, E$ \\
\hline & Constructive Role & B & $J^{*}, E^{*}$ & $I, E$ \\
\hline
\end{tabular}

$K=$ The amount of profit media generates resorting to TRP oriented programme.

$J=$ The amount of profit media generates resorting to programmes which are educative and beneficial to the society and also the amount of profit media generates resorting to TRP oriented programme when the community do not watch them. The symbol $(*)$ means there is a possibility in the long run to increase the value.

$I=$ The amount of profit media generates resorting to constructive programmes when the community do not watch it. In this case $I<J<K$.

$E=$ The amount of utility that the community derives by remaining idle.

$F=$ The amount of utility community derives by watching attractive but not educative programmes being in a otherwise stagnant dull society.

$E^{*}=$ Same as $E$ but due to the fact that educative programmes are not entertaining enough in the short run but beneficial in the long run. In this case $E<E^{*}<F$.

\section{Findings}

1. Strategy $(A, 1)$ is the Nash Equlibrium.

2. Socially desirable strategy is $(\mathrm{B}, 1)$.

3. Media can increase the value of $E^{*}$ greater than $F$ in the long run if it catches the imagination and appreciation of the community and thus can also increase the value of $J^{*}$ so that $J^{*}>K$.

\section{GAME SIMULATION: 5}

\section{State and non-state civil society body and Community}

Not only media but also government, women's organisations, NGOs have a collective role to play in curbing the problem of witch hunting. Although in short run police actions are the most opted strategy, but it is not effective in the long run. The true solution lies in educating the people, providing easily accessible healthcare facilities, mode of communication, transportation, changing the mindset of common people etc. This very fact has been shown in the following table with Administration and Civil Society Organs (NGOs, Press, Women's Organization etc.) as Player 1 and the affected community as Player 2.

Table 10. Pay-off Matrix between the players State and Community

\begin{tabular}{|c|c|c|c|c|}
\hline $\begin{array}{cc}\text { Players } & \rightarrow \\
\downarrow & \\
\end{array}$ & \multicolumn{4}{|c|}{ Community } \\
\hline \multirow{4}{*}{ 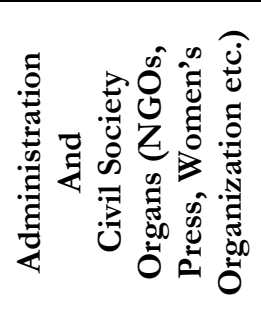 } & Strategies $\rightarrow$ & & Cooperate & Do not Cooperate \\
\hline & $\downarrow$ & & 1 & 2 \\
\hline & $\begin{array}{c}\text { Police Action } \\
\text { (Evidence } \\
\text { Collection) } \\
\end{array}$ & A & $V,-e$ & $-U, 0$ \\
\hline & Constructive Role & B & $\begin{array}{c}W, F \\
\text { (Nash } \\
\text { Equilibrium) }\end{array}$ & $-(U+k), 0$ \\
\hline
\end{tabular}

Here, $V$ and $(-U)$ are the utility and disutility generated to the society as a whole resorting to police action when the particular community cooperates and does not cooperate respectively. $V>-U$ because nabbing a culprit in occurrence of any witch hunting case sends a strong message to other parts of the whole society and thus prevents to some extent future happenings in other parts also. Failed police action can not affect the society to the same extent although negatively. Community's utility remains constant at 0 (zero) irrespective of other player's strategy if they do not cooperate. In case they cooperate in police action the witness will get some disutility $(-e)$ as he is to live and remain in the same community against whom he becomes a witness. In case of constructive role of player 1 the community derives utility $F$ which is highest among all in the table (i.e. $F>0>-e$ ) basically 
due to two reasons. (i) Any new programme in the locality brings a change in their otherwise dull life. (ii) In the long run, constructive role will enable them to view any further problem with scientific outlook. For the society as a whole a successful set of Strategy $(\mathrm{B}, 1)$ will generate social benefit amounting $W$. But if in spite of the effort from NGOs and administration the affected community do not cooperate the disutility will also be high at - $(U+$ $k$ ). It is higher than Strategy A2 because failed police effort leaves a criminal scot-free but failed constructive effort keeps the possibility of further crime alive.

\section{Findings}

1. Police action can not bring permanent solution to this problem as their objective is limited (evidence collecting) and there is high possibility that the community is not going to cooperate.

2. Strategy $(B, 1)$ is the Nash Equilibrium and also it is the socially most desirable strategy.

3. The very fact that in spite of the socially desirable strategy being the Nash Equilibrium the occurrence of witch hunting is coming to light at an increasing rate proves that the civil society organs lack co-ordination and have much to do as the community is ready to accept it.

\section{PART D: FINDINGS AND RECOMMENDATIONS}

From the preceding discussions and simulations several findings come out (Table 11).

Table 11. Findings and summary of the Game simulations

\begin{tabular}{cl}
\hline Table in Reference & \multicolumn{1}{c}{ Desired Interference } \\
\hline Table 5 & $\begin{array}{l}\text { Restrict Community's Choice to Strategy } 1 \text { nipping the problem in the bud. In other words, no } \\
\text { matter what comes from nature, community's strict choice should be resorting to scientific ways. }\end{array}$ \\
\hline Table 6 & $\begin{array}{l}\text { Restrict the culprit in the socially desirable strategy i.e. A ('Leave the victim alone'). The prevailing } \\
\text { social as well as judicial structure should assign the value of the pay-offs for the culprit so that it is } \\
\text { always better for the culprit not to disturb the victim and for the victim it is always comfortable to } \\
\text { ask for community's help. }\end{array}$ \\
\hline Table 7 & $\begin{array}{l}\text { It is important to develop 'Others options' (i.e. the Strategy } 3 \text { of community) apart from already } \\
\text { existing two strategies. i.e. Participate (Strategy 1) and no participation (Strategy 2). }\end{array}$ \\
\hline Table 8 & $\begin{array}{l}\text { Culprit should be confined in the Strategy A by increasing the probabilities to choose Strategies } 2 \\
\left.\text { and } 3 \text { ( } p_{2} \text { and } p_{3}\right) \text { and also the probability to get the culprit punished ( } m, n, p \text { and } q \text { ) along with } \\
\text { the increase in punishment (i.e. } X \text { ) can reduce witch hunting. }\end{array}$ \\
\hline Table 9 & $\begin{array}{l}\text { Media should put more focus on its constructive contribution to the society rather than TRP } \\
\text { oriented approach. }\end{array}$ \\
\hline Table 10 & $\begin{array}{l}\text { Strategy }(\mathrm{B}, 1) \text { is the Nash equilibrium as well as socially desirable point. The constructive role of } \\
\text { the government appears to be the best option for the society in the long run. }\end{array}$ \\
\hline
\end{tabular}

The recommendations that follow the above findings are enlisted below:

1. Develop a rational scientific atmosphere across communities through widespread education and enlarging medical facilities even in the remotest areas. Increased healthcare facilities and heath awareness will enable the population to emancipate from linking health problems from superstitious beliefs. This will gradually reduce witch accusations and witch hunting. Moreover, frequent awareness programmes on social problems will also help in removing the stigmas attached to witch accusations, in case there is any.

2. It is necessary to develop an atmosphere in the society where victim does not feel reluctance to ask for community help and there is high chance of culprit to be punished if guilty. Introduce a $24 \times 7$ helpline number exclusively for the purpose of preventing 'witch-hunting' cases and encourage people to use it through prompt action.

3. Ensure a people friendly police set up so that anyone from the community can inform police in case of any occurrence of witch-hunting case. Police forces should be given problem specific training to be sensitive to such issues and become more efficient.

4. Ensure fast track court and avoid perplexing judicial procedures to establish instances of punishment to the culprits.

5. Media should try to incorporate educative elements in the programmes which catch the imagination and appreciation of the common rural people. Constructive role of Media should be encouraged by the government with rewards.

6. Government should take more proactive role through the ways which captures the imagination of common rural people like showing bioscopes, arranging street plays by different groups etc.

7. Ensure proper co-ordination among different elements working to prevent witch-hunting. Most importantly, unless a frontal attack on superstitions is made, all efforts will fail. People should be made 
aware of the past witch hunting cases with the background stories through media and NGOs so that rural people can see any witch related case rising above superstitions.

\section{REFERENCES}

BBC News [online] Available at: http://www.bbc.com/news/world-asia-india-29655662 [Accessed 20 October 2014].

BBC News [online] Available at: http://www.bbc.com/news/world-south-asia-12149785 [Accessed 23 April 2015].

Chakraborty, J. and Borah, A. (2013). Witch hunting in Assam: Strategising Alternative Media for Women Empowerment and Overcoming Superstition. Journal of North East India Studies, 3(2), pp. 15-24.

Chaudhuri, S. (2014). Unusual Expressions of Social Protest: Witchcraft accusations in Jalpaiguri, India. CAS Working Paper Series, CAS/WP/14-5, JNU, New Delhi.

Federici, S. (2008). Witch-Hunting, Globalization, and Feminist Solidarity in Africa Today. New York: The Commoner.

Gibbons, R. (1992). A primer in game theory. New Delhi: Prentice Hall.

Gura, E. and Maschler, M. (2008). Insights into game theory: An alternative mathematical experience. Cambridge: Cambridge University Press.

Handique, B. (2010). Witch-bunt victims narrate nigbtmares. The Telegraph, Daily English Newspaper December, 11, 2010.

Hart, S. (2006). Robert Aumann's Game and Economic Theory. Scandinavian Journal of Economics, 108(2), pp185211.

Indian Express Newspaper [online] Available at: http://archive.indianexpress.com/news/witchhunt-island--for22-days-35-people-in-assams-majuli-put-through-purification/1187638/0 [Accessed 20 October 2014].

National Crime Records Bureau. (2015). Crime in India 2014. New Delhi: Ministry of Home Affairs (Government of India).

Ochoche, J.M. (2013). Modeling Boko Haram: A Game Theoretical Approach. International Journal of Science and Technology, 2(11), pp. 777-783.

Pradhan, K. and Guzman, O.D. (2013). A curse in the family (Documentary), Aljazeera. [online] Available at: https://www.academia.edu/2496768/youtube_link_on_A_Curse_in_the_Famly_by_Orlando_de_Guzman [Accessed 31 October 2014].

Saikia, K. (2011). Rights violations and witch-hunting cases. In: A. Borkataki and N. Sharma, ed., Women issues and perspectives. Nagaon: Anandaram Dhekial Phookan College.

Saikia, S.P. (2015). Witch-Hunting Perspectives with Special Reference to the Rabha Community of Goalpara District, Assam: A Draft Eradication Strategy. In: P.C. Dash and T. Nayak, ed., Witch Hunting in Assam, Guwahati: Binapani Publishing House.

Tsebelis, G. (1990). Are Sanctions Effective?: A Game Theoretic Analysis. Journal of Conflict Resolution, 34(1), pp. 328.

Turocy, T.L. and Stengel, B. (2001). Game Theory. CDAM Research Report. Prepared for Encyclopaedia of information systems.

Varian, H.R. (1992). Microeconomic Analysis, New York: W.W. Norton \& Company, pp. 259-284. 